Bangladesh J. Pl. Breed. Genet, 24(1): 15-22

\title{
HOMESTEAD FRUIT SPECIES DIVERSITY IN THE HAOR AREA OF BANGLADESH
}

\author{
M. S. Islam, M. M. Haque and M. A. Mannan ${ }^{1}$ \\ Department of Genetics and Plant Breeding \\ Faculty of Agriculture, Sher-e-Bangla Agricultural University \\ Dhaka 1207, Bangladesh
}

\begin{abstract}
Diversity of fruit species, species richness and relative prevalence of species were investigated in the Haor area of Bangladesh. A total of 27 fruit species belonging to 19 families were identified. Among 27 fruit species, coconut, mango and jujube were found in the $100 \%$ homestead surveyed. The relative prevalence of the most common species such as banana, betel nut, coconut, mango, papaya and guava were very high while pineapple, litchi was found very low. Coconut and mango were found highly diversed (0.990) fruit species followed by guava $(0.986)$ and papaya $(0.987)$. It is necessary to take special attention towards the fruit production system and fruit diversity in the study areas.
\end{abstract}

Key words: Homestead, species diversity, haor area, Bangladesh

\section{INTRODUCTION}

The well-being of the growing world population depends on the availability of biodiversity. Tropical fruits can provide an important source of income and nutrition. Fruits in the daily diet have been strongly associated with reduced risk for some forms of cancer, heart disease, stroke, and other chronic diseases (Goldberg, 2003, Hyson, 2002, Prior and Cao, 2000; Southon, 2000).

Bangladesh is an agro- based country and almost attained self-sufficiency in cereal food. Fruit production is very limited and the consumption of fruit, we depend on foreign supplies. It offers a highly congenial environment for the growth of varieties of fruits like banana, papaya, pineapple, litchi, jackfruit etc, which are more nutritious compared to the imported foreign fruits like orange, grape, apple etc. Our fruit production is not sufficient to meet up our domestic demand. During last five decades population of Bangladesh increased from 75 million to 152.81 million (BBS, 2011), simultaneously food grain production increased from 10 million to about 32 million tons (BBS, 2011). But fruit production did not increase at the same rate. Day $^{-1}$ person ${ }^{-1}$, the minimum dietary requirement of fruit is $85 \mathrm{~g}$, whereas our availability is only $30-35 \mathrm{~g}$. In view of the fact, the consumption and availability of fruits is very negligible. As a result, imbalanced nutrition and nutrition deficiency diseases such as xerophthalmia, rickets, scurvy, iron-deficiency anemia are being increased at an alarming rate.

There are 25.53 million homesteads in Bangladesh (BBS, 2011). Homestead fulfill basic needs of the people such as fruit, food, shelter, cash etc and high species

\footnotetext{
${ }^{1}$ Department of Agricultural Extension (DAE), Ministry of Agriculture, Khamrbari Dhaka 1207, Bangladesh
} 
diversity of the homestead help to reduce the environmental deterioration commonly associated with monoculture production system.

A large area of every homestead remain as fallows because of poor plant population whereas plantation of diversified fruit trees in planned way considering the harvesting period, a farmer can easily get year round fruit supply from his homestead garden and can get more production of fruit from their garden. Therefore, fruit diversity in homestead is necessary (Sellathurai, 1997). But no study was so far carried out solely on the status of homestead fruit diversity in the Haor area of Bangladesh. It is necessary to develop suitable plans and fruit production system for fruit diversification in Haor homestead. Therfore, it is very important to have a clear understanding of the present position of Haor homestead fruit diversity and the factors related to fruit diversity in homestead of the farmers. Fruit diversity and its relationship with farmer's helpful for planning and implementing effective fruit diversification program to increase balanced food intake of the farm family. Therefore, a survey was carried out to identify the fruit species being grown and the magnitude of diversity of fruits in the homesteads of Haor of Bangladesh.

\section{MATERIALS AND METHODS}

The study was carried out in the Haor area during April to September, 2011. It is located in Ajmiriganj upazila of Hobigonj district in Bangladesh under the AEZ-21 (Brammer, 1971). The soil $\mathrm{pH}$ of this area ranges from 6.6-8.3 and the organic matter content ranges from $0.6 \%$ to $2.3 \%$. The geographical positions of the survey area between $24^{\circ} 30^{\prime}$ to $24^{\circ} 38^{\prime}$ North latitude and between $91^{\circ} 10^{\prime}$ to $91^{\circ} 22^{\prime}$ East longitude. The lowest and the highest temperatures are generally recorded $13.6^{\circ} \mathrm{C}$ and $33.2^{\circ} \mathrm{C}$ respectively. In Bangladesh there are six seasons However there are visible distinctly. May to October is rainy, November to February is winter and March to April is summer season.

The study area is significant because natural vegetations were rich compared to the other areas of Bangladesh. According to the size of homestead area, samples of 300 homesteads were selected for each category under five unions. They were grouped into five farm categories like marginal (up to 10 decimals), small (11-30 decimals), medium (31-50 decimals), large (51-100 decimals) and very large (more than 100 decimals). The collected data were verified through survey the villages and discussion with fruit grower. Informations was collected from primary and secondary sources and complied by survey as well as non-survey methods. The survey sources include interviews through a pretested interview schedule; key informant and farmer's group discussion while nonsurveys include the information through field survey, direct observations and secondary sources. The interview schedule was pre-tested with 10 homesteads and then final shape was given to the interview schedule. Data for fruit diversity of the homestead were collected using questionnaire. Information was recorded through interviews of family members like head of the family, housewife and others. Data were collected mainly on name and numbers of fruit species, demographical characteristics of the homesteads, socio-economic information. In this study only fruit species was identified and calculated. Relative Prevalence (RP) of species was calculated by using the following formula: $\mathrm{RP}=$ Population of the species per homestead $\times \%$ Homestead with the species. These relative prevalence values were used to rank the species in different regions (Millat-e-Mustafa, 1997). The mean dominance rank was determined by pooling the entire set of data of all the three regions the most commonly used formula of Simpson (1949) index (D) was used to calculate species diversity (D) as follows:

$$
\mathrm{D}=1-\mathrm{E}_{\mathrm{p}} \mathrm{i}^{2}
$$


Where,

$\mathrm{P}$ is the proportional abundance of the i species,

$\mathrm{P}=\mathrm{N}_{\mathrm{i}} / \mathrm{N}$

$\mathrm{N}=$ Plant population of $\mathrm{i}^{\text {th }}$ species and

$\mathrm{N}=\mathrm{N}_{1}+\mathrm{N}_{2}+\mathrm{N}_{3}+\ldots$ $\mathrm{N}$

Where $\mathrm{N}$ is the number of species

Fruit diversity was described under the headlines of species richness, relative prevalence of species and species diversity. The collected data were compiled, tabulated, coded and analyzed in accord with the objectives of the study. Qualitative data were quantified by means of scoring techniques. The statistical measures such as number and distribution were used for describing the variables of the study. Microsoft Excel programs were used to process all collected information. To estimate the descriptive statistics of the data SPSS software, 2006 was used.

\section{RESULTS AND DISCUSSION}

\section{Species richness}

A wide range of fruit species were found in the study area. Twenty seven fruit species were identified in the homesteads surveyed which are commonly use for human consumption. The list of the identified fruit species was presented in the Table 1 . The total number of fruit species per homestead in five different unions is shown in Table 3. The higher number of fruit species was found in larger farms and less number of fruit species was found in smaller farms.

Table 1. Species richness of fruits in the study area

\begin{tabular}{lllll}
\hline English Name & Local Name & Scientific Name & Family \\
\hline Banana & Kola & Musa sp & Musaceae \\
Betel nut & Supari & Areca catechu & Palmaceae \\
Black berry & Jam & Syzygium cumini & Myrtaceae \\
Burmese grape & Lotkon & Baccaurea ramiflora & Phyllanthaceae \\
Carrabolla & Kamranga & Averrhoa carambola & Agerrhoaceae \\
Coconut & Narikel & Cocos nucifera & Palmae \\
Custard apple & Ata & Anona squamosa & Annonaceae \\
Date & Khejur & Phoenix sylvestris & Palmaceae \\
Elephant apple & Chalta & Dillenia indica & Dilleniaceae \\
Gooseberry & Arboroi & Phyllanthus acidus & Euforbiaceae \\
Guava & Peara & Psidium guajava & Myrtaceae \\
Hog plum & Amra & Spondias dulcis & Anacardiaceae \\
Indian apple & Bel & Aegle marmelos & Rutaceae \\
Indian Goose Berry & Amloki & Phyllanthus embelica & Euforbiaceae \\
Indian jujube & Kul & Zizyphus mauritiana & Rhamnaceae \\
Jackfruit & Khathal & Artocarpus heterophyllus & Moraceae \\
Lemon & Lebu & Citrus limon & Rutaceae \\
Litchi & Lichu & Litchi chinensis & Sapindaceae \\
Mango & Aam & Mangifera indica & Anacardiaceae \\
Olive & Jalpai & Elaeocarpus floribundus & Elaeocarpaceae \\
Orange & Komla & Citrus chrysocarpa & Rutaceae \\
Palmyra palm & Tal & Borassus flabellifer & Palmaceae \\
Papaya & Papaya & Carica papaya & Caricaceae \\
Pomegranate & Dalim & Punica granutum & Punicaceae \\
Tamarind & Tetul & Tamarrinbus indica & Fadaceae \\
Velvet apple & Gab & Piospyros discolor & Ebenaceae \\
Wax jumbo & Jamrul & Syzygium samarangense & Myrtaceae \\
\hline & & &
\end{tabular}


From this survey it was observed that species richness and fruit diversity of homestead is increasing day by day but the increasing rate is very low. The distribution of the plant species was influenced by macro and micro environmental factors of the homestead and the needs and choices of the family members. Species richness varied from one location to another and from one farm category to another.The observed 27 fruit species were belonged to different family and 19 families were identified with these 27 species presented in Table 2. Among these families, Myrtaceae, Rutaceae and Palmaceae are dominant.

Table 2. Families with number of species observed in the study area

\begin{tabular}{lcllc}
\hline Family name & Species number & Family name & Species number \\
\hline Myrtaceae & 3 & Elaeocarpaceae & 1 \\
Palmaceae & 3 & Fadaceae & 1 \\
Rutaceae & 3 & Moraceae & 1 \\
Anacardiaceae & 2 & Musaceae & 1 \\
Euforbiaceae & 2 & Palmae & 1 \\
Agerrhoaceae & 1 & Phyllanthaceae & 1 \\
Annonaceae & 1 & Punicaceae & 1 \\
Caricaceae & 1 & Rhamnaceae & 1 \\
Dilleniaceae & 1 & Sapindaceae & 1 \\
Ebenaceae & 1 & & \\
\hline
\end{tabular}

The number of fruit producing species was higher than other species in each home garden. The farmers concentrate on fruit species because of their subsistence and cash need. Mango, coconut, banana, guava, betel nut, papaya, lemon, black berry were cultivated in the most of the homesteads. Among them, mango, coconut, banana, guava, betel nut and lemon were the dominant species in homesteads at all locations and had the most diverse utility among all other fruit species. It was found that fifty-seven different varieties were grown within 150 homesteads of Haor of Bangladesh. It was varied depending upon the family choice.

\section{Relative prevalence of species}

The relative prevalence of fruit species found in 300 homesteads of this study area are presented in Table 3. The relative prevalence of most common species are betel nut, banana, mango, coconut, guava, jackfruit, lemon and black berry were very high while that of less common species like burmese grape, goose berry, Indian goose berry, plamyra palm and orange were found very low. Mango was the most prevalent among the horticultural species followed by guava, jackfruit, coconut and jujube (Alam et al. 1990). It was reported that coconut was the most prevalent where among the fruit species followed by jackfruit, date palm, banana and mango in Bangladesh (Chowdhury and Satter, 1992). Mannan (2000) also observed mango as the most prevalent among the fruit species followed by jackfruit, guava, jujube and coconut in Bangladesh. Ecological factor is one of the determinants of species grown in the farms. Besides the ecological reasons, the socio-economic conditions of the homesteads were a major determinant of the species-mix prevailing in a home garden. There were minor differences in relative prevalence of less common species but significant differences of most common species among the farm categories. Especially farmers were giving the preference to grow for particular fruit species in their homesteads. The decision of which trees to grow depended on a combination of price and yield, the location of the farm in terms of ecological zone and consumption center. 
Table 3. Relative prevalence of different fruit species in the study area

\begin{tabular}{l|l|l|l|l|l|l}
\hline \multirow{2}{*}{ Name of species } & \multicolumn{5}{|c|}{ Unions } & \multirow{2}{*}{ Total } \\
\cline { 2 - 6 } & Ajmirigonj & Kakailcheo & Bodolpur & Jolshukha & Sibpasha & Tot \\
\hline Betel nut & 75.60 & 54.54 & 206.01 & 174.69 & 64.53 & 115.074 \\
Banana & 31.86 & 58.05 & 109.89 & 51.30 & 120.69 & 74.358 \\
Mango & 61.83 & 62.91 & 48.06 & 86.94 & 58.05 & 63.558 \\
Coconut & 65.88 & 86.67 & 51.84 & 66.42 & 38.88 & 61.938 \\
Papaya & 7.29 & 22.14 & 62.64 & 28.35 & 30.78 & 30.240 \\
Guava & 14.04 & 37.8 & 34.02 & 23.49 & 17.82 & 25.434 \\
Jackfruit & 13.50 & 35.64 & 26.73 & 8.91 & 4.86 & 17.928 \\
Lemon & 12.69 & 9.99 & 22.14 & 12.96 & 18.36 & 15.228 \\
Black berry & 16.20 & 9.45 & 21.06 & 13.23 & 11.61 & 14.310 \\
Indian jujube & 3.78 & 9.18 & 17.01 & 7.29 & 2.43 & 7.938 \\
Elephant apple & 0.81 & 1.08 & 7.83 & 7.83 & 2.16 & 3.942 \\
Olive & 1.62 & 3.24 & 10.53 & 3.24 & 0.81 & 3.888 \\
Indian apple & 2.43 & 1.62 & 11.34 & 2.43 & 1.35 & 3.834 \\
Litchi & 3.51 & 5.94 & 4.05 & 2.7 & 0.27 & 3.294 \\
Hog plum & 1.62 & 2.97 & 5.67 & 2.7 & 2.7 & 3.132 \\
Custard apple & 1.35 & 4.86 & 2.97 & 3.51 & 1.89 & 2.916 \\
Pomegranate & 2.16 & 0.54 & 3.51 & 1.35 & 2.16 & 1.944 \\
Wax jumbo & 1.62 & 1.35 & 4.59 & 1.89 & 0.27 & 1.944 \\
Tamarind & 0.00 & 0.00 & 2.97 & 0.00 & 1.35 & 0.864 \\
Carrabolla & 1.08 & 0.81 & 0.27 & 0.81 & 0.00 & 0.594 \\
Date & 0.00 & 0.27 & 1.89 & 0.27 & 0.00 & 0.486 \\
Velvet apple & 0.00 & 0.00 & 1.89 & 0.27 & 0.00 & 0.432 \\
Orange & 0.81 & 0.54 & 0.00 & 0.27 & 0.00 & 0.324 \\
Palmyra palm & 0.00 & 0.27 & 0.27 & 0.81 & 0.00 & 0.270 \\
Indian Goose Berry & 0.54 & 0.00 & 0.00 & 0.00 & 0.27 & 0.162 \\
Burmese grape & 0.00 & 0.27 & 0.00 & 0.00 & 0.27 & 0.108 \\
Gooseberry & 0.27 & 0.00 & 0.00 & 0.00 & 0.27 & 0.108 \\
\hline
\end{tabular}

The fruit species were ranked according to their relative prevalence in five different unions viz Ajmirigonj, Kakailcheo, Bodolpur, Jolshukha and Sibpasha (Table 4). Among 27 fruit species, guava, elephant apple, hog plum, betel nut and Indian goose berry were found in the around 100\% homestead surveyed. Banana was found the most prevalent in all the unions except Ajmirigonj where betel nut was the most prevalent one. The next prevalent species were coconut, mango and date. It was reported by Mannan (2000) that mango was the most prevalent followed by guava, jackfruit and coconut.

\section{Distribution of the species}

In general, frequency of a particular species is one of the indications of its biodiversity in that specific area. It was observed that coconut and mango were found in $80 \%$ homestead in the study area followed by guava $(63.67 \%)$, papaya $(51.67 \%)$, betel nut $(46.67 \%)$ and black berry (42\%) (Table 5). Among the others banana, lemon, pomegranate were found at more than $30 \%$ homesteads. Abedin et al. (1990) found mango at $95 \%$ homesteads of Tangail and above $67 \%$ homesteads of Ishurdi, Jessore, and Rangpur. It was reported that mango, jackfruit, coconut and banana were available at more than 65\% homesteads of Jessore (Alam et al., 1990). 
Table 4. Ranking of fruits in different union according to their relative prevalence in the study area

\begin{tabular}{|c|c|c|c|c|c|c|}
\hline \multirow[t]{2}{*}{ Name of species } & \multicolumn{5}{|c|}{ Unions } & \multirow[b]{2}{*}{ Total } \\
\hline & Ajmirigonj & Kakailcheo & Bodolpur & Jolshukha & Sibpasha & \\
\hline Custard apple & 17 & 8 & 20 & 13 & 15 & 27 \\
\hline Indian jujube & 10 & 24 & 17 & 8 & 24 & 26 \\
\hline Black berry & 5 & 18 & 16 & 9 & 12 & 25 \\
\hline Jackfruit & 7 & 12 & 14 & 26 & 27 & 24 \\
\hline Date & 24 & 20 & 12 & 14 & 20 & 23 \\
\hline Pomegranate & 13 & 15 & 10 & 25 & 16 & 22 \\
\hline Papaya & 9 & 17 & 8 & 21 & 25 & 21 \\
\hline Olive & 15 & 10 & 25 & 27 & 22 & 20 \\
\hline Burmese grape & 23 & 7 & 18 & 15 & 11 & 19 \\
\hline Palmyra palm & 25 & 26 & 21 & 22 & 26 & 18 \\
\hline Velvet apple & 27 & 16 & 7 & 12 & 10 & 17 \\
\hline Lemon & 8 & 22 & 23 & 5 & 23 & 16 \\
\hline Litchi & 11 & 5 & 22 & 20 & 17 & 15 \\
\hline Tamarind & 26 & 27 & 15 & 11 & 7 & 14 \\
\hline Indian apple & 12 & 14 & 26 & 23 & 5 & 13 \\
\hline Banana & 4 & 21 & 27 & 17 & 6 & 12 \\
\hline Mango & 3 & 9 & 13 & 16 & 9 & 11 \\
\hline Orange & 20 & 13 & 11 & 6 & 4 & 10 \\
\hline Gooseberry & 22 & 23 & 3 & 7 & 14 & 9 \\
\hline Wax jumbo & 16 & 6 & 4 & 24 & 13 & 8 \\
\hline Carrabolla & 18 & 11 & 6 & 3 & 8 & 7 \\
\hline Coconut & 2 & 4 & 24 & 18 & 21 & 6 \\
\hline Indian Goose Berry & 21 & 19 & 5 & 19 & 3 & 5 \\
\hline Betel nut & 1 & 3 & 9 & 10 & 19 & 4 \\
\hline Hog plum & 14 & 25 & 19 & 2 & 2 & 3 \\
\hline Elephant apple & 19 & 2 & 1 & 4 & 18 & 2 \\
\hline Guava & 6 & 1 & 2 & 1 & 1 & 1 \\
\hline
\end{tabular}

Table 5. Distribution of fruit species in the homesteads of five unions

\begin{tabular}{|c|c|c|c|c|c|c|}
\hline \multirow[t]{2}{*}{ Name of species } & \multicolumn{5}{|c|}{ Unions } & \multirow[b]{2}{*}{ Total } \\
\hline & Ajmirigonj & Kakailcheo & Bodolpur & Jolshukha & Sibpasha & \\
\hline Coconut & 73.33 & 93.33 & 85.00 & 80.00 & 71.67 & 80.67 \\
\hline Mango & 78.33 & 90.00 & 80.00 & 80.00 & 68.33 & 79.33 \\
\hline Guava & 35.00 & 75.00 & 81.67 & 81.67 & 45.00 & 63.67 \\
\hline Papaya & 16.67 & 61.67 & 85.00 & 38.33 & 56.67 & 51.67 \\
\hline Betel nut & 28.33 & 38.33 & 81.67 & 46.67 & 38.33 & 46.67 \\
\hline Black berry & 38.33 & 28.33 & 53.33 & 48.33 & 41.67 & 42.00 \\
\hline Banana & 11.67 & 38.33 & 48.33 & 26.67 & 55 & 36.00 \\
\hline Lemon & 40.00 & 18.33 & 63.33 & 31.67 & 26.67 & 36.00 \\
\hline Jackfruit & 18.33 & 33.33 & 41.67 & 25.00 & 13.33 & 26.33 \\
\hline Indian jujube & 11.67 & 23.33 & 50.00 & 16.67 & 10.00 & 22.33 \\
\hline Carrabolla & 13.33 & 8.33 & 38.33 & 18.33 & 21.67 & 20.00 \\
\hline Olive & 10.00 & 15.00 & 38.33 & 13.33 & 5.00 & 16.33 \\
\hline Hog plum & 3.33 & 13.33 & 30.00 & 13.33 & 18.33 & 15.66 \\
\hline Indian apple & 13.33 & 11.67 & 36.67 & 8.33 & 6.67 & 15.33 \\
\hline Custard apple & 11.67 & 28.33 & 18.33 & 6.67 & 10.00 & 15.00 \\
\hline Elephant apple & 6.67 & 5.00 & 28.33 & 8.33 & 15.00 & 12.67 \\
\hline Litchi & 13.33 & 20.00 & 18.33 & 10.00 & 1.67 & 12.67 \\
\hline Pomegranate & 10.00 & 3.33 & 15.00 & 8.33 & 8.33 & 9.00 \\
\hline Wax jumbo & 1.67 & 1.67 & 10.00 & 5.00 & 1.67 & 4.00 \\
\hline Palmyra palm & 1.67 & 1.67 & 1.67 & 3.33 & 8.33 & 3.33 \\
\hline Date & 5.00 & 1.67 & 3.33 & 1.67 & 3.33 & 3.00 \\
\hline Tamarind & 1.67 & 1.67 & 10.00 & 0.00 & 0.00 & 2.67 \\
\hline Velvet apple & 1.67 & 0.00 & 3.33 & 1.67 & 5.00 & 2.33 \\
\hline Orange & 8.33 & 0.00 & 0.00 & 0.00 & 1.67 & 2.00 \\
\hline Indian Goose Berry & 3.33 & 0.00 & 0.00 & 0.00 & 1.67 & 1.00 \\
\hline Burmese grape & 1.67 & 0.00 & 0.00 & 0.00 & 1.67 & 0.67 \\
\hline Gooseberry & 1.67 & 0.00 & 0.00 & 0.00 & 1.67 & 0.67 \\
\hline
\end{tabular}




\section{Species diversity}

Diversity of fruit species varied from region to region and species to species. To know the plant biodiversity, species diversity was calculated considering the five unions as a whole. It might help to understand the fruit diversity in respect of Ajmiriganj. Species diversity of fruit was varied from 0 to 0.992 in the study area (Table 6). Mango and coconut were found highly diversed fruit species which was 0.992 and 0.990 , respectively. The second highest intra species diversity was found in papaya (0.987), banana and guava (0.986) and 22 species of fruits were having a low diversity in this study area.

Table 6. Species diversity of fruit in the homesteads of five unions in the study area

\begin{tabular}{|c|c|c|c|c|c|c|}
\hline \multirow[t]{2}{*}{ Name of species } & \multicolumn{5}{|c|}{ Union } & \multirow[b]{2}{*}{ Total } \\
\hline & Ajmirigonj & Kakailcheo & Bodolpur & Jolshukha & Sibpasha & \\
\hline Mango & 0.960 & 0.969 & 0.958 & 0.958 & 0.961 & 0.992 \\
\hline Coconut & 0.951 & 0.944 & 0.964 & 0.969 & 0.966 & 0.990 \\
\hline Papaya & 0.859 & 0.964 & 0.956 & 0.932 & 0.948 & 0.987 \\
\hline Banana & 0.835 & 0.938 & 0.946 & 0.878 & 0.958 & 0.986 \\
\hline Guava & 0.783 & 0.940 & 0.961 & 0.96 & 0.927 & 0.986 \\
\hline Black berry & 0.846 & 0.885 & 0.905 & 0.945 & 0.935 & 0.978 \\
\hline Hog plum & 0.611 & 0.843 & 0.93 & 0.84 & 0.880 & 0.973 \\
\hline Jackfruit & 0.835 & 0.909 & 0.905 & 0.836 & 0.852 & 0.971 \\
\hline Lemon & 0.572 & 0.789 & 0.927 & 0.883 & 0.840 & 0.966 \\
\hline Indian jujube & 0.765 & 0.863 & 0.906 & 0.700 & 0.716 & 0.962 \\
\hline Betel nut & 0.811 & 0.941 & 0.868 & 0.798 & 0.928 & 0.960 \\
\hline Custard apple & 0.800 & 0.926 & 0.876 & 0.627 & 0.816 & 0.960 \\
\hline Olive & 0.778 & 0.889 & 0.897 & 0.861 & 0.444 & 0.960 \\
\hline Indian apple & 0.864 & 0.833 & 0.904 & 0.716 & 0.720 & 0.957 \\
\hline Pomegranate & 0.813 & 0.5 & 0.757 & 0.720 & 0.813 & 0.943 \\
\hline Litchi & 0.817 & 0.798 & 0.791 & 0.600 & 0.000 & 0.942 \\
\hline Wax jumbo & 0.722 & 0.72 & 0.685 & 0.653 & 0.000 & 0.903 \\
\hline Carrabolla & 0.75 & 0.667 & 0.000 & 0.444 & 0.000 & 0.893 \\
\hline Tamarind & 0.000 & 0.000 & 0.793 & 0.000 & 0.800 & 0.883 \\
\hline Elephant apple & 0.667 & 0.750 & 0.875 & 0.250 & 0.750 & 0.858 \\
\hline Velvet apple & 0.000 & 0.000 & 0.694 & 0.000 & 0.000 & 0.750 \\
\hline Palmyra palm & 0.000 & 0.000 & 0.000 & 0.444 & 0.000 & 0.720 \\
\hline Berry & 0.500 & 0.000 & 0.000 & 0.000 & 0.000 & 0.667 \\
\hline Orange & 0.835 & 0.500 & 0.000 & 0.000 & 0.000 & 0.667 \\
\hline Date & 0.835 & 0.000 & 0.245 & 0.000 & 0.000 & 0.519 \\
\hline Gooseberry & 0.000 & 0.000 & 0.000 & 0.000 & 0.000 & 0.500 \\
\hline Burmese grape & 0.000 & 0.000 & 0.000 & 0.000 & 0.000 & 0.000 \\
\hline
\end{tabular}

\section{CONCLUSIONS}

This study would be the foundation for the policy makers to understand the species richness, fruit species conservation, and socio-economic importance of homestead as well as to formulate biodiversity conservation planning highlighting homestead of Bangladesh for sustainable production and maintenance of biodiversity.

\section{ACKNOWLEDGEMENTS}

This work was supported by the BAS-USDA fund under the project of "Modeling of year round fruit production at Haor homestead" in Bangladesh. 


\section{REFERENCES}

Abedin, M. Z. and M. A. Quddus. 1990. Homesteads fuel situation, home gardens and agroforestry practices at six agro-ecologically different locations of Bangladesh (Abedin et al. eds.). Proceedings of a national workshop held 17-19 July 1988 in Joydebpur, Bangladesh. BARI/RWEDP/WINROCK, pp: 19-53.

Alam, M. S., M. F. Haque, M. Z. Abedin and S. Akter. 1990. Homestead trees and homesteads fuel uses in and around the FSR site, Jessore. In: Homestead plantation and agroforestry in Bangladesh. By M. Z. Abedin, C. K. Lai and M. O. Ali (Eds.). BARI Joydebpur Bangladesh, pp: 106-119.

BBS, 2011. Statistical Year Book of Bangladesh, Bangladesh Bureau of Statistics. Ministry of Planning. Dhaka.

Brammer, H. 1971. Soil Resources. Soil survey project Bangladesh. Agril. St. Pak. 6.Technical Reports. UNDP/FAO.

Chowdhury, M. K. and M. A. Satter. 1992. Agroforestry practice in traditional farming system of Bangladesh. A report prepared for BARC/Winrock Intl., Dhaka, Bangladesh.

Goldberg, G. (ed). 2003. Plants: Diet and Health. The report of a British Nutrition Foundation Task Force. Blackwell Publishing, Oxford, U.K. pp.347.

Hyson, D. 2002. The health benefits of fruits and vegetables. A scientific overview for health professionals. Produce for Better Health Foundation, Wilmington DE. pp. 20.

Mannan M. A, M. A. K. Mian, M. A. Aziz and N. Haq. 2004. Evaluation of some stone originated Mango Accession. Bangladesh J. Plant Breed. Genet. 17(1): 25-29.

Mannan, M. A. 2000. Plant biodiversity in the homestead of Bangladesh and its utilization in Crop improvement. Ph.D. thesis, Bangabandhu Sheikh Muzibur Rahman Agricultural University, Gazipur 1706, Bangladesh.

Millat-e-Mustafa, M. 1997. Floristic and Indigenous Management Techniques of Homegardens in Bangladesh. In: Agroforestry: Bangladesh Perspective. By M. K. Alam, F. U. Ahmed and S. M. R. Amin (Eds.). APAN, NAWG, BARC, Bangladesh.

Prior, R. L. and G. Cao. 2000. Antioxidant phytochemicals in fruits and vegetables; diet and health implications. Hort. Sci. 35: 588-592.

Sellathurai, P. 1997. Homegarden Agroforestry and sustainability in Kandy district, Srilanka. M.Sc. Thesis. Agricultural University of Norway.

Simpson, E. H. 1949. Measurement of diversity. Nature. 163: 688.

Southon, S. 2000. Increased fruit and vegetable consumption within the EU: potential health benefits. Food Res. Intl. 33:211-217.

SPSS (Statistical Package for Social Sciences), 2006. SPSS (Computer based software package) v. 16. SPSS Inc., New York. 